УДК $82-3$

Чередник Л. А., кандидат филологических наук, доцент, Полтавский национальный технический университет имени Юрия Кондратюка

\title{
М. БУЛГАКОВ В ОЦЕНКЕ Г. АДАМОВИЧА
}

У статті аналізуються роботи одно з найвидатніших критиків російської еміграції ХХ століття Г. Адамовича, присвячені раннім творам М. Булгакова. Критик підкреслює майстерність письменника, притаманні йому історизм, сатиричну спрямованість $i$ критичне ставлення до дійсності.

Ключові слова: література, критика, повість, роман, герой, сатира, історизм.

В статье анализируются работы одного из самых крупных критиков русской эмиграчии ХХ века Г. Адамовича, посвященных ранним произведениям М. Булгакова. Критик отмечает мастерство писателя, присущие ему историзм, сатирическую направленность и критическое отношение к действительности.

Ключевые слова: литература, критика, повесть, роман, герой, сатира, историзм.

The article analyzes the works of one of the biggest critics of the Russian emigration of the twentieth century G. Adamovich, dedicated to the early works of Mikhail Bulgakov. The critic points out the writer's skill, inherent historicism, satirical focus and a critical attitude towards reality.

Keywords: literature, criticism, story, novel, character, satire, historicism.

Критические статьи занимают значительное место в творческом наследии русского поэта-акмеиста и переводчика Г. В. Адамовича, которое, к большому сожалению, остается до сих пор недостаточно изученным.

Известно, что дебют Г. Адамовича в этом жанре состоялся в 1915 году, а после расстрела Н. Гумилева он стал главным критиком петербургского «Цеха Поэтов». Но этот период можно считать пробой пера. Как известно, критический талант писателя расцвел в эмиграции. Именно с 1923 года, когда 
Адамович покинул Россию, он регулярно выступал с критическими статьями и эссе, которые печатал в журнале «Звено» (1923 - 1928 гг.), газете «Последние новости» (с 1928 года).

На протяжении 1923 - 1924 годов статьи Г. Адамовича появлялись почти в каждом номере «Звена». Их тематика самая разнообразная: заказные рецензии, обзоры французских журналов и т. д. Работы молодого критика, которые в этот период он сам именовал то «Литературными размышлениями», то «Литературными заметками», отличались яркой оригинальностью и глубиной. Именно эти качества позволили ему, по мнению одного из крупнейших русских поэтов-эмигрантов Георгия Иванова, превратится из «ничем не примечательного петербургского поэта, одного из многочисленных учеников Гумилева, в первого критика эмиграции» [Коростылев 1998:2]. Высоко отзывались о критических работах Г. Адамовича и другие писатели и исследователи. Например, И. Бунин назвал его «лучиим критиком в эмиграциии». Ю. Иваск, русский поэт, литературный критик, американский историк русской литературы, подчеркивал, что Г. Адамович - «замечательныц критик, лучший русский критик нашего времени» [Адамович 1998:367].

Современный литературовед О. Коростылев акцентирует внимание на необыкновенной широте интересов Адамовича-критика. «Он следил не только за эмигрантской словесностью, в круг его интересов входили вопросы религии теологии, философии и политики» [Коростылев 1998:14]. Кроме того Г. Адамович писал о театре, музыке, кино, русском языке, о французской, английской, американской литературах, о русской классике. Следил критик и за советской литературой, «всматривался, вслушивался в нее, огорчался, много раз ее хоронил, а затем всматривался и вчитывался вновь» [Коростылев 1998:15]. В центре нашего исследования - критические эссе Г. Адамовича по поводу нескольких ранних произведений М. Булгакова.

Из современной тогдашней советской литературы внимание критика привлекла повесть М. Булгакова «Роковые яйца», напечатанная в 1925 году на страницах альманаха «Недра» (№ 6). Это произведение было высоко оценено 
современными русскими литераторами (за исключением В. Шкловского), но изза острой социальной проблематики голоса советских критиков разделились. Одни (Ю. Соболев, А. Вронский и др.) восхищались произведением, другие автора ругали, называли контрреволюционером, белогвардейским, «совершенно идеологически неоформленным» писателем» [Гудкова 1989:675].

Г. Адамовичу, который впервые познакомился с творчеством М. Булгакова, повесть понравилась, он назвал ее «любопьтной» и посоветовал прочитать «всем, кто может «Недра» раздобыть», назвав при этом сам альманах «захудальмм советским журнальчиком» [Адамович 1998:204]. Любопытно, что произведение М. Булгакова привлекло внимание критика среди, как он сам выразился, «всевозможной дребедени, подписанной именами Н. Никандрова, Н. Тихонова и М. Волошина» [Адамович 1998:204], напечатанной в этом же номере журнала.

В своей небольшой статье критик писал: «Роковые яйщฺ» имеют одно огромное и необычайное достоинство: повесть чрезвычайно интересна, ее читаешь, не отрываясь, в один присест. Крайнее своеобразие замысла, богатство выдумки в подробностях, легкость изложения - все этому cnособствует» [Адамович 1998:204]. Кроме того, Г. Адамович смог уловить сатирическую направленность произведения, обнаружил сходство манеры молодого Булгакова с Гофманом и Гоголем. Интересной, по мнению критика, является удивительная «способность автора найти грань между смешным $u$ трагическим, не впадая ни в то, ни в другое» [Адамович 1998:204]. По мнению критика, первая часть повести является более удачной, но автору не хватает мастерства так же оригинально закончить произведение: «Повесть ведется сначала в подчеркнуто сатирическом тоне, к кониу сбиваясь на какую-то эпопею» [Адамович 1998:204]. Недостаточно убедительным он считает и описание Москвы 1928 года как «гигантского, кипящего котла».

И еще: современного читателя, пожалуй, не может не поразить та истинная интеллигентность, можно сказать, даже осторожность, с которой известный критик не торопится делать заключение о творчестве писателя, 
познакомившись лишь с одним из его произведений. Г. Адамович отмечал: «Нужна чересчур большая самонадеянность, чтобы по первой вещуи высказаться решительно. Внимание к этому имени, во всяком случае, возбуждено» [Адамович 1998:204]. И в этом его позиция резко отличалась от многих советских критиков того периода, привыкших «приклеивать» ярлыки, исходя уже из первого попавшегося им в руки произведения.К анализу творчества М. Булгакова, «самыцй влиятельный литературный критик русской эмиграциии», по словам литературоведа В. Вейдле, обратился еще раз. В «Литературных беседах» за 1927 год появляется статья, посвященная первой части романа «Дни Турбиных», изданном в Париже (так во французском издании назывался роман «Белая гвардия»).

В начале статьи Г. Адамович, предостерегая от излишне поспешных суждений, корректно предлагает дождаться того момента, когда роман будет полностью напечатан (как известно, вторая часть романа увидела свет только в 1929 году). Отмечая, что в книге «встречаются страницы небрежные и не совсем удачные» [Адамович 1998:160], критик все же выделяет ее из всех русских романов того периода. Его привлекло то, что «в «Днях Tурбиных» есть широкий и свободный размах, уверенность настоящего дарования, что оно с чем угодно справится, и та расточительность, на которую только большое дарование способно» [Адамович 1998:160].

Очень точно подмечено влияние на автора Л. Толстого, особенно ощутимое в изображении героев. Известно, что в творчестве великого классика русской литературы XIX века всегда наблюдался колоссальный интерес к человеку как к самобытному и самооценочному явлению, которое, в то же время, сильно зависит и от внешних объективных факторов, таких как, история, общество и т.д. Толстовские герои всегда обращают свой взор в глубины своей души, пытаясь найти именно там опору и поддержку в борьбе с внешними обстоятельствами. Этим объясняются душевные искания всех положительных героев Толстого и тот принцип нравственного самоусовершенствования человека, который проповедует писатель. 
М. Булгаков, по мнению Г. Адамовича, очень удачно перенимает этот принцип изображения персонажей, создавая не общий тип, а индивидуальность с множеством мелких, пусть даже едва уловимых, черт. «Никакого искажения, ни малейшего привкуса фальши в его очерках и обрисовках нет, - как это ни удивительно для «советского» писателя! Его люди - настоящче люди» [Адамович 1998:160].

На страницах булгаковского романа ощущается глубокое сочувствие к героям, свойственное и его великому предшественнику. Через много лет известный современный русский литературовед Н. Степанов в монографии «Сатира М. Булгакова в контексте русской сатиры XIX - I пол. XX века» также подчеркнет эту особенность автора «Белой гвардии»: «Булгаков утверждает приоритет общзечеловеческих изенностей над идеологическими догмами и классовыми понятиями» [Степанов 1999:208].

Г. Адамович также отмечал, что «Булгаков первый понял, или, точнее вспомнил, что человек есть всегда главная тема и предмет литературы, и с этим сознанием он коснулся револючии, в которой до сих пор полагалось видеть только «массы»» [Адамович 1998: 160].

Глубина критики Г. Адамовича проявилась еще и в том, что он уловил критическое отношение автора к изображаемому периоду. Известно, что к времени создания романа М. Булгаков уже осознавал весь ужас того, что принес с собой октябрьский переворот 1917 года. Писатель констатирует в романе, что прошлая жизнь канула в Лету. Лучшая часть гибнущего старого мира представлена белой гвардией. Но Турбины и их друзья растеряны, они мучительно ищут ответа на вопрос: «Как жить дальше?». Отсюда весь драматизм и сложность восприятия нового мира, которое ощущается уже с первых строк романа: «Велик был год и страшен год по Рождестве Христовом 1918, от начала же револющчии второй. Был он обилен летом солнцем, а зимою снегом, и особенно высоко в небе стояли две звезды: звезда пастушеская вечерняя Венера и красный дрожащчий Марс» [Булгаков 1990:179]. 
Кроме того, М. Булгаков изображает своих героев в сложный для них период: они побеждены, выброшены из привычной жизни. По мнению Г. Адамовича, «с жадностью настоящего художника Булгаков обратил все свое внимание в сторону побежденных: в несчастиях и поражениях человек душевно богаче и сложнее, щуедрее, интереснее для наблюдателя, чем в торжестве и успехах» [Адамович 1998:160].

Как известно, в романе образы офицеров становятся воплощением лучших человеческих качеств, и вместе с этими образами возникает тема «русская интеллигенция и революция», которая была актуальной для литературы тех лет. Позиция М. А. Булгакова, отражённая в творчестве, конечно, сложнее и глобальнее, чем односторонний классовый подход в произведениях отдельных советских писателей. Намного позже, в «Письме Правительству СССР» от 28 марта 1930 года М. Булгаков писал, что в романе «Белая гвардия» он дал «изображение интеллигентско-дворянской семьи, волею непреложной исторической судьбы брошенной в годы гражданской войны в лагерь белой гвардии в традициях «Войны и мира». Такое изображение вполне естественно для писателя, кровно связанного с интеллигенцией» [Булгаков 1990:447].

Анализируя роман, критик отмечает способность автора объективно оценивать изображаемое в романе, что и позволяет Г. Адамовичу назвать «Дни Турбиных» М. Булгакова «первым действительно “художественным" произведением, имеющим отношение к револющии» [Адамович 1998:160].

Отмечая безусловную художественную ценность романа, Г. Адамович подчеркивал, что тот является превосходным свидетельством о времени. «Это роман не исторический, - но он с историей связан, и комментирует он ее умно, зорко и с той «горечью», которая лежит в основе всех несуесловных рассуждений, наблюдений и писаний о жизни» [Адамович 1998:161].

Как известно, в современном литературоведении это называется принципом историзма, который проявился в произведении, прежде всего в 
точной характеристике политических сил, борьба между которыми развертывается не только на страницах романа, но и в реальной жизни.

Таким образом, можно сделать выводы о том, статьи Г. Адамовича привлекли внимание читателей-эмигрантов к творчеству известного русского писателя XX века М. Булгакова. Критик отмечал, что в творческой манере современного писателя чувствуется влияние его великих предшественников Н. Гоголя и Л. Толстого.

Г. Адамович верно обозначил сатирическую направленность повести «Роковые яйца», историзм романа «Дни Турбиных» и принцип изображения персонажей, а также критическое отношение автора к изображаемому. Такой взгляд на мир, по мнению критика, присущ истинно талантливому писателю и дает право относиться к литературе как к «человеческому документу» [Петрова 2010:82]. И это еще раз дает возможность подчеркнуть мысль о том, что Г. Адамович «всегда был склонен рассматривать литературу не просто как ремесло, профессию, но видеть за ней нечто большее и соответственно к этому относиться» [Коростылев 1998:14].

\section{БИБЛИОГРАФИЯ}

Адамович 1998 - Адамович Г. В.Собрание сочинений. Литературные беседы: Книга первая. («Звено»: 1923 - 1926) / Г. В. Адамович - СПб. : Алетейя, 1998. - 574 с.

Адамович 1998 - Адамович Г. В. Собрание сочинений. Литературные беседы: Книга вторая. («Звено»: 1926 - 1928) / Г. В. Адамович - СПб. : Алетейя, 1998. $-510 \mathrm{c}$.

Булгаков 1989 - Булгаков М. А. Собрание сочинений: В 5 т./ М. А. Булгаков - М. : Художественная литература, 1989. - 622 с.

Булгаков 1990 - Булгаков М.А. Собрание починений : В 5 т. / М. А. Булгаков - М. : Художественная литература, 1990. - 734 с. 
Гудкова 1989 - Гудкова В. Повести Михаила Булгакова // М. А. Булгаков. Собрание сочинений: В 5 т. / Редколл.: Г. Гоц, А. Караганов, В. Лакшин и др. : Подгот. текста и коммент. В. Гудковой и Л. Фиалковой/ В. Гудкова. - М. : Художественная литература, 1989. - С. 663-713.

Коростылев 1998 - Коростелев Олег. Подчиняясь не логике, но истине... (предисловие) // Адамович Г. В. Литературные беседы. Книга первая. («Звено»: 1923-1926) / Олег Коростелев - СПб. : Алетейя, 1998. - С. 2-15.

Петрова 2010 - Петрова Т. Г. Литературная критика русской эмиграции первой волны (Современные отечественные исследования): Аналит. обзор / РАН. ИНИОН. Центр гуманит. науч.-информ. исслед. Отд. литературоведения; Отв. редактор Е. А. Цурганова / Петрова Т. Г. - М., 2010. - 136 с.

Степанов 1999 - Степанов Н. С. Сатира М.Булгакова в контексте русской сатиры XIX - I пол. XX века / Н. С. Степанов - Винница, 1999. - 282 с. 